\title{
Treatment of early rheumatoid arthritis with rifampicin
}

\author{
N L Cox, M V Prowse, M C Maddison, P J Maddison
}

\begin{abstract}
Following a report that seven of 20 patients with rheumatoid arthritis (RA) had come into clinical and laboratory remission after treatment with rifampicin, and that six of the seven responders had a disease duration of less than three years, 21 patients with classical or definite RA of recent onset were treated with $600 \mathrm{mg}$ rifampicin and $300 \mathrm{mg}$ isoniazid daily for six months. Fourteen of 21 patients completed six months' treatment, but there was no significant improvement in the mean values of the clinical and laboratory parameters measured. The improvement suggested by preliminary studies in patients with early RA is not seen in this larger group. In patients with a disease duration of less than 18 months, however, there was a significant decrease in the erythrocyte sedimentation rate and the serum concentrations of $C$ reactive protein after treatment for six months, although there was no significant clinical improvement. Future studies of this drug in patients with RA should concentrate on this group.
\end{abstract}

A wide variety of drugs is available to treat patients with rheumatoid arthritis (RA). Most are potentially toxic and their efficacy is limited, so it is controversial whether or not any drug currently used for treating rheumatoid arthritis has any significant effect on the long term outcome of the patient. ${ }^{1}$

Individual drugs have often been used empirically. The intramuscular gold salts, known to have antituberculous properties, were used in patients with RA and were found to be effective. ${ }^{2}$ Seven of 20 patients with RA treated with rifampicin with or without isoniazid for six months improved significantly, both clinically and in terms of laboratory parameters. ${ }^{3}$ In six of these seven patients the duration of RA was less than three years. This observation suggests that rifampicin might have a disease suppressing effect or, better still, may halt the progress of the disease in patients in the early stages of RA.

Rifampicin, a complex macrocyclic antibiotic, and isoniazid, a hydrazide of nicotinic acid, are accepted as first line drugs in the treatment of tuberculosis. Their possible efficacy in patients with rheumatoid arthritis is intriguing. Since Forestier's time there has been interest in the role of immunity to mycobacterial antigens in patients with RA. Injection of Freund's adjuvant, for example, containing a suspension of $\mathrm{Myco-}$ bacterium tuberculosis in mineral oil, induces a polyarthritis in susceptible strains of rats. ${ }^{4}$ More recently, subjects with HLA-DR4, a phenotype linked to increased susceptibility to RA, have been shown to have enhanced immunity to mycobacterial strains compared with subjects with other DR types. ${ }^{5}$ However, on epidemiological grounds, $M$. tuberculosis seems unlikely to be a cause of RA. Rifampicin, however, is effective against a wide range of extra- and intracellular microorganisms, including perhaps any putative agent causing RA. Rifampicin also causes immunosuppression in humans and laboratory animals, although much of the evidence for this is conflicting. ${ }^{6}$

There are anecdotal reports of RA improving in patients with coexisting tuberculosis treated with rifampicin and this drug has been reported to protect against adjuvant arthritis in rats. ${ }^{7}$ Furthermore, intra-articular injection of rifamycin SV, a rifampicin derivative, has been reported to be effective in the treatment of rheumatoid synovitis of the knee. ${ }^{89}$ Not all studies of the treatment of RA by rifampicin given by mouth have shown efficacy. ${ }^{10}$ In this study we explored further the possibility that this drug might be effective in the treatment of patients in the early stages of RA.

\section{Patients and methods}

Twenty one patients with classical or definite seropositive $\mathrm{RA}^{10}$ of less than three years duration were entered into the study. All patients had active RA, as confirmed by a Ritchie score of 12 or more, early morning stiffness of more than $\mathbf{3 0}$ minutes duration and an erythrocyte sedimentation rate of at least 20 $\mathrm{mm} /$ hour. No patient had taken a disease modifying drug for RA for at least four months. Patients with hepatic or renal impairment and women of childbearing age not using adequate contraception were excluded from the study. Informed consent was obtained from all patients.

Combination tablets containing $300 \mathrm{mg}$ rifampicin and $150 \mathrm{mg}$ isoniazid were given in a dose of two tablets daily for the duration of the study.

The following assessments were made at zero, two, four, and six months. (a) clinical: Ritchie score, grip strength, duration of early morning stiffness, pain score using a $100 \mathrm{~mm}$ visual analogue scale, and a health assessment questionnaire. (b) Laboratory: haemoglobin, erythrocyte sedimentation rate, $C$ reactive protein, rheumatoid factor by the sheep cell agglutination test, white blood cell count, and liver function tests (transaminases, alkaline phosphatase and $\gamma$-glutamyltranspeptidase).

Side effects were determined by a neutral 
question: 'Has the treatment upset you in any way?'

Statistical analysis was performed with the Wilcoxon signed rank test.

\section{Results}

Twenty one patients were entered into the study (19 women, two men, average age 60.5 years), with an average disease duration of 16.6 months. Tables 1-4 summarise the results. In the group as a whole there was no significant improvement in any of the variables after six months. Only five of 21 patients chose to continue taking rifampicin and isoniazid after the trial period had finished. Of these five, two patients were in remission nine and 12 months, respectively, after their treatment was stopped. One patient deteriorated after stopping rifampicin and isoniazid, but did not improve after a further three months of treatment. Fifteen patients with a disease duration of less than 18 months were analysed separately. Table 3 shows that after six months there was a significant decrease in the erythrocyte sedimentation rate and levels of $\mathrm{C}$ reactive protein, and a rise in haemoglobin level. There was, however, no significant clinical change.

\section{Discussion}

In this series of patients, the results are no better than might be expected from the natural history of RA. Our results are less promising than those of McConkey and Situyanake. ${ }^{3}$ Open studies such as these are limited by the small sample size, non-randomised design, and the lack of a control group for comparison. Therefore, the reasons for the different results must remain speculative. There are, however, two possible explanations. Firstly, the only significant difference between the responders and non-responders in the study of McConkey and

Table 1 Overall outcome of patients after six months of treatment

\begin{tabular}{ll}
\hline Outcome & No of patients \\
\hline No benefit & 9 \\
Non-compliance & 3 \\
Treatment withdrawn owing to side effects & 4 \\
Possible benefit & 4 \\
Improved & 3 \\
\hline
\end{tabular}

Table 3 Effect of rifampicin in patients with rheumatoid arthritis with a disease duration of less than six months

\begin{tabular}{|c|c|c|c|}
\hline \multirow[t]{2}{*}{$\begin{array}{l}\text { Clinical and } \\
\text { laboratory features }\end{array}$} & \multicolumn{2}{|c|}{$\begin{array}{l}\text { Duration of } \\
\text { treatment (months) }\end{array}$} & \multirow[t]{2}{*}{ p Value } \\
\hline & 0 & 6 & \\
\hline $\begin{array}{l}\text { Duration of early } \\
\text { morning stiffness (min) } \\
\text { Ritchie index } \\
\text { Pain score }(\mathrm{mm}) \\
\text { Health assessment } \\
\text { questionnaire score }(0-24) \\
\text { Erythrocyte sedimentation } \\
\text { rate }(\mathrm{mm} / \mathrm{h}) \\
\text { C reactive protein (mg/l) } \\
\text { Haemoglobin }(\mathrm{g} / \mathrm{l})\end{array}$ & $\begin{array}{l}95(110) \\
23(9) \\
54(19) \\
11 \cdot 7(5 \cdot 1) \\
65(33) \\
410(290) \\
120(20)\end{array}$ & $\begin{array}{l}47(31) \\
290(210) \\
126(16)\end{array}$ & $\begin{array}{c}<0.001 \\
0.04 \\
0.03\end{array}$ \\
\hline
\end{tabular}

Results are given as mean (SD).

Table 4 Side effects in seven patients who failed to complete six months of treatment with rifampicin

\begin{tabular}{ll}
\hline $\begin{array}{l}\text { Reason for withdrawal } \\
\text { (No of patients) }\end{array}$ & $\begin{array}{l}\text { Time of } \\
\text { withdrawal (weeks) }\end{array}$ \\
\hline Defaulted (1) & 16 \\
Stopped at patient's request (1) & 16 \\
Moved away from area (1) & 8 \\
Withdrawn after major relapse (1) & 8 \\
Severe vomiting (1) & 2 \\
Severe diarrhoea (1) & 3 \\
Withdrawn owing to melaena stools (1) & 8 \\
\hline
\end{tabular}

Situyanake $^{3}$ was the duration of disease. All the responders had a duration of disease of 18 months or less, whereas we included patients who had had RA for up to 36 months; our mean duration of disease was 16.6 months. In the open study of rifampicin reported by Gabriel $e t$ $a l,{ }^{10}$ which showed little effect in eight patients, the mean disease duration was 13 years (range 4.5-27). Earlier disease is more likely to remit spontaneously and this might have biased the results of McConkey and Situyanake. ${ }^{3}$ If, however, RA is regarded as being triggered by an infection which later becomes self perpetuating, any antimicrobial treatment might be expected to be more effective the earlier it is started. Therefore, we examined the results for patients in our study who had had RA for less than 18 months. There was no apparent clinical improvement after six months of treatment, although there was evidence of suppression of the acute phase response.

Secondly, our patients had more severe disease than those in the previous study ${ }^{3}$ from the point of view of the clinical features and the laboratory values. Our patients were slightly older, with a

Table 2 Clinical and laboratory measurements of patients during six months of treatment

\begin{tabular}{|c|c|c|c|c|}
\hline \multirow[t]{2}{*}{ Measurement } & \multicolumn{4}{|c|}{ Months after start of treatment } \\
\hline & $\begin{array}{l}0 \\
(n=21)\end{array}$ & $\begin{array}{l}2 \\
(\mathrm{n}=19)\end{array}$ & $\begin{array}{l}4 \\
(n=16)\end{array}$ & $\begin{array}{l}6 \\
(n=14)\end{array}$ \\
\hline $\begin{array}{l}\text { Duration of early morning } \\
\text { stiffess (min) } \\
\text { Ritchie index } \\
\text { Pain score }(\mathrm{mm}) \\
\text { Grip strength }(\mathrm{mmHg})\end{array}$ & $\begin{array}{l}97(133) \\
24(9 \cdot 3) \\
55(22 \cdot 3) \\
115(32)\end{array}$ & $\begin{array}{l}73(113) \\
22(11 \cdot 5) \\
42(27 \cdot 7) \\
113(26)\end{array}$ & $\begin{array}{l}97(151) \\
22(13 \cdot 1) \\
47(31 \cdot 4) \\
123(38)\end{array}$ & $\begin{array}{r}122(215) \\
21(11 \cdot 3) \\
43(34 \cdot 7) \\
119(39)\end{array}$ \\
\hline $\begin{array}{l}\text { Health assessment questionnaire } \\
\text { score }(0-24) \\
\text { Haemoglobin }(\mathrm{g} / \mathrm{l})\end{array}$ & $\begin{array}{l}13(5 \cdot 5) \\
122(21)\end{array}$ & $\begin{array}{c}14(5 \cdot 8) \\
122(15)\end{array}$ & $\begin{array}{r}13(4 \cdot 9) \\
123(15)\end{array}$ & $\begin{array}{l}12(6 \cdot 6) \\
122(13)\end{array}$ \\
\hline $\begin{array}{l}\text { Erythrocyte sedimentation } \\
\text { rate }(\mathbf{m m} / \mathbf{h}) \\
\text { C reactive protein }(\mathrm{mg} / \mathrm{l}) \\
\text { SCAT reciprocal titre* }\end{array}$ & $\begin{array}{c}69(32) \\
460(300) \\
1280\end{array}$ & $\begin{array}{l}65(26) \\
480(280) \\
640\end{array}$ & $\begin{array}{l}56(34) \\
390(300) \\
320\end{array}$ & $\begin{array}{l}56(36) \\
380(280) \\
320\end{array}$ \\
\hline
\end{tabular}


higher average age $(60.5$ years) than might be expected for patients in the early stages of RA. It is possible that chance selection gave an unrepresentative sample of patients with RA. In our study, 14 patients came from a rheumatological practice in a district general hospital and seven from a specialist centre also taking tertiary referrals. The patients from the two centres had very similar demographic and clinical features.

The only other major difference between the two studies was the geographical location. This raises the unlikely possibility that RA could respond differently in different geographical locations, implying a variety of different triggering infections.

Only 14 of the 21 patients continued the treatment for six months and two of those were withdrawn owing to side effects after six months of treatment. This compares unfavourably with other second line agents presently used to treat patients with RA. Any further studies of rifampicin and isoniazid in patients with RA should probably be confined to patients in the very early stages of the disease and should compare active treatment with a placebo group.

1 Scott D L, Coulton B L, Symmons D P M, Popert A J. Long term outcome of treating rheumatoid arthritis: results after 20 years. Lancet 1987; i: 1108-11.

2 Forestier J. Rheumatoid arthritis and its treatment by gold salts. Lancet 1934; ii: 646-8.

3 McConkey B, Situyanake D. Effects of rifampicin with and without isoniazid in rheumatoid arthritis. $\mathcal{f}$ Rheumatol 1988; 15: 46-50.

4 Pearson C M. Development of arthritis, periarthritis and periostitis in rats

5 Ottenhoff T H M, Torres P, de las Aguas J T, et al. Evidence for a HLA Dr4-associated immune response gene for Mycobacterium tuberculosis. Lancet 1986; ii: 310-13.

6 Nessi R, Pallanza R, Fowst G. Rifampicin and immunosuppression. Arzneimittelforschung 1974; 24: 832-6.

7 Arrigoni-Martelli E, Schiatti D, Selva D. Rifampicin and alanosine inhibition of adjuvant arthritis in rats. Pharmacol Res 1971; 3: 329-33.

8 Cottafava F, Pinelli G, Freschi P A, et al. Sinovite reumatoide albumin ginoccho trattata con buon risultato con rifamicina S V intraartielare. Minerva Pediatr 1982; 34: 33-7.

9 Caruso I, Montrone F, Fumagalli M, et al. Rheumatoid knee synovitis successfully treated with intra-articular rifamycin SV. Ann Rheum Dis 1982; 41: 232-6.

10 Gabriel S E, Conn D L, Luthra H. Rifampicin therapy in rheumatoid arthritis. F Rheumatol 1990; 17: 163-6.

11 Kirwan J, Reeback J S. Stanford health questionnaire modified to assess disability in British patients with rheumatoid arthritis. Br $\mathcal{F}$ Rheumatol 1986; 25: 206-9. 